Jan Rymarczyk

\title{
RECENZJA MONOGRAFII EUGENIUSZA \\ M. PLUCIŃSKIEGO,KONKURENCYJNOŚĆ \\ STRUKTURALNO-CZYNNIKOWA POLSKIEGO \\ HANDLU NA RYNKU UE W LATACH 2002-2012. \\ WYBRANE ASPEKTY Z PERSPEKTYWY \\ RACJONALNYCH WYBORÓW W GOSPODARCE \\ OTWARTEJ ORAZ EFEKTÓW DOBROBYTOWYCH INTEGRACJI EUROPEJSKIEJ"
}

DOI: $10.15611 / \mathrm{e} .21 .2016 .1 .10$

Recenzowana praca obejmuje 340 stron, w tym 284 strony to właściwy tekst, a pozostałe to obszerny aneks statystyczny (33 strony), bibliografia oraz spis tabel, schematów i rysunków. Jest to optymalna i uzasadniona podjętą tematyką objętość. Książka ma charakter empiryczno-teoretyczny i oparta została na obliczeniach własnych Autora bazujących na krajowych i międzynarodowych statystykach oraz bogatej, dobrze dobranej literaturze przedmiotu w języku polskim, angielskim i niemieckim, z wykorzystaniem pozycji źródłowych, a także wydawnictw periodycznych i informacji internetowych. Zaprezentowana problematyka stanowi kontynuację prowadzonych przez Autora od wielu lat badań nad przemianami w polskim handlu zagranicznym, jego rozmiarami, dynamiką, strukturą, konkurencyjnością i efektywnością, szczególnie w kontekście członkostwa Polski w Unii Europejskiej. Niewątpliwie M. Pluciński należy do czołówki polskich naukowców zajmujących się tymi kwestiami, a jeśli chodzi o badanie procesu przejścia Polski od handlu międzygałęziowego do wewnątrzgałęziowego, co jest przedmiotem recenzowanej monografii, to jego osiągnięcia są, moim zdaniem, największe na tle całego dorobku badawczego polskich ekonomistów zgłębiających tę problematykę.

Wybrany przez Autora problem jest bardzo ważny z punktu widzenia naukowego, ponieważ jego zbadanie wzbogaca naszą wiedzę o przebiegu, determinantach i efektach zmian w handlu zagranicznym średniej wielkości kraju - określanego jako emerging market - polegających na przejściu od tradycyjnego (międzygałęziowego) modelu podziału pracy do nowoczesnego (wewnątrzgałęziowego) modelu w kontekście rozwoju procesów integracji gospodarczej, czyli jej przechodzenia w 
coraz wyższe stadia rozwoju. Przeprowadzone przez Autora badania w jego dalszej pracy naukowej mogą posłużyć do skonstruowania teoretycznego modelu takiego rozwoju handlu międzynarodowego integrujących się średnio rozwiniętych krajów.

Niezwykle ważny jest również utylitarny aspekt badań przeprowadzonych przez M. Plucińskiego. Odnoszą się one bowiem do Polski i stanowią nie tylko ilustrację zmian w konkurencyjności strukturalnej jej gospodarki na rynku Unii Europejskiej, ale także ich ocenę ze względu na lukę, jaka istnieje pomiędzy rzeczywistymi (osiągniętymi) przez Polskę korzyściami dobrobytowymi a potencjalnymi. Dobrze udokumentowany stan rzeczy i jego przyczyny stanowią podstawę do cennych wskazań zawartych w zakończeniu pracy, czyli odpowiedzi na pytania, co należy zrobić, aby nastąpiły pożądane zmiany strukturalno-czynnikowe polskiego eksportu i naszej roli w unijnym modelu podziału pracy. $Z$ tego względu należy uznać, że praca adresowana jest przede wszystkim do decydentów - polityków zajmujących się gospodarką, albo raczej do ich doradców, ponieważ jak wykazuje praktyka, nie mają oni czasu na studiowanie rozpraw naukowych lub, co jest jeszcze ważniejsze, są one dla nich za trudne. Nie oznacza to, że monografia nie będzie przydatna także dla innych środowisk. Z pewnością jej lektury nie powinni pominąć pracownicy naukowi, prowadzący badania i zajęcia dydaktyczne $\mathrm{z}$ handlu międzynarodowego, międzynarodowych stosunków gospodarczych, biznesu międzynarodowego czy międzynarodowej ekonomii, oraz studenci tych kierunków, przynajmniej jeśli chodzi o pewne jej partie, zwłaszcza dotyczące sfery teoretyczno-wnioskowej.

Dobór metod badawczych dokonany przez Autora należy uznać za prawidłowy i efektywny, to znaczy prowadzący do pełnej realizacji założonych celów pracy oraz umożliwiający weryfikację sformułowanych we wstępie pracy hipotez badawczych. W monografii zdecydowanie przeważają metody empiryczne nad teoretycznymi. Analiza empiryczna (danych statystycznych) dotyczy handlu Polski z Unią Europejskiej w wybranych latach: 2002-2004-2014, z podziałem na kraje stare - UE15 i nowe - UE10+2, a także odrębnie Eurolandu. Autor przeprowadził ją poprzez wyliczenia wielu wskaźników, opierając się na danych międzynarodowej klasyfikacji handlu SITC Rev. 3,4. Podstawowe znaczenie miała analiza branżowych i gałęziowych wskaźników RCA i IIP w handlu Polski z UE jako całością i jej poszczególnymi krajami. Pozwoliła ona Autorowi odpowiedzieć na kluczowe pytania pracy dotyczące tempa i charakteru dostosowań w zakresie strukturalnej konkurencyjności Polski na rynku Unii Europejskiej oraz ustalić naszą pozycję w porównaniu z nowoczesnym modelem handlu, który dominuje pomiędzy starymi krajami UE, a także wskazać związane z tym wyzwania dla Polski.

Analiza empiryczna poprzedzona została rozważaniami teoretycznymi skoncentrowanymi w dwóch pierwszych rozdziałach pracy. Autor, opierając się na różnych teoriach handlu międzynarodowego, zaczynając od klasycznych, a kończąc na popytowo-podażowych, scharakteryzował problem racjonalnych wyborów ekonomicznych w gospodarce otwartej i efektów dobrobytowych na poziomie mikroi makroekonomicznym w kontekście rozwoju międzynarodowej integracji gospo- 
darczej, w tym przede wszystkim integracji europejskiej i jej stadiów rozwoju. W drugim rozdziale „Fazy integracji gospodarczej (UE) ) vs efekty dobrobytowe z międzynarodowego podziału pracy i migracji czynników produkcji” przedstawił także istotę i metodologię pomiaru handlu międzygałęziowego (RCA) i wewnątrzgałęziowego (IIT). Zgodnie z ogólnometodologiczną zasadą badań naukowych przechodzenie „od ogółu do szczegółu” w kolejnych czterech rozdziałach, tj. IV-VI, M. Pluciński konkretyzuje problem badawczy zasygnalizowany w tytule pracy, czyli dokonuje analizy konkurencyjności strukturalno-czynnikowej polskiego handlu na rynku Unii Europejskiej w wybranych przedziale czasowym, tj. w latach 2002-2012. W rozdziale III zatytułowanym „Rola rynku UE w handlu Polski ze światem z makroekonomicznymi parametrami w tle" Autor dokonuje analizy polskiego handlu zagranicznego w ogóle, a szczególnie z Unią Europejską.

W IV rozdziale „Dynamika zmian konkurencyjności czynnikowej polskiego eksportu w handlu między- i wewnątrzgałęziowym na rynku UE15 /2002 - 2004 - 2012/" na podstawie wyliczonych przez siebie wskaźników RCA i IIT Pluciński przedstawia zmiany konkurencyjności czynnikowej prowadzące do zmian w udziale handlu między- i wewnątrzgałęziowego w UE15, a także Polski z wybranymi krajami UE (Niemcy, Francja, Włochy, Holandia, Wielka Brytania).

Kolejny, tj. V rozdział, zatytułowany „Handel Polski z nowymi krajami UE $10+2$ vs konkurencyjność strukturalno-czynnikowa w latach 2004-2012”, ma podobny charakter jak poprzedni, czyli również dotyczy konkurencyjności strukturalno-czynnikowej polskiego handlu, ale w tym przypadku w relacji do nowych krajów o zbliżonym do Polski poziomie rozwoju.

Ostatni rozdział pracy pt. „Integracja UE z USA (TTIP) z perspektywy intensyfikacji udziału Polski w handlu wewnątrzgałęziowym na rynku UE 15" ma charakter prognostyczny. Autor po scharakteryzowaniu handlu Polski z USA stara się przewidzieć, jakie skutki dla polskiego handlu będzie miało utworzenie transatlantyckiej megaintegracji, tj. strefy wolnego handlu między UE a USA (Transatlantic Trade and Investment Partnership), wskazując wyraźnie na potencjalne korzyści dla rozwoju technologicznego i w konsekwencji na wzrost udziału handlu wewnątrzgałęziowego w strukturze polskiego handlu zagranicznego.

Pracę kończy rozbudowany punkt „Zakończenie i wnioski”, w którym w wyczerpujący sposób przedstawiono aspekty opisu problemów ustalenia związków przyczynowo-skutkowych, utylitarności, czyli wskazań dla formułowania polskiej polityki gospodarczej, która byłaby adekwatna do wyzwań stojących przed gospodarką i handlem zagranicznym Polski w dobie gospodarki opartej na wiedzy i globalizacji, oraz prognozy, czyli możliwego scenariusza rozwoju sytuacji „quo vadis Polsko?", zwłaszcza gdy nie będą podjęte działania zapobiegające degradacji pozycji Polski w handlu unijnym i światowym.

W sumie konstrukcję pracy należy uznać za prawidłową i spełniającą wymogi logiczno-formalne, tj. dotyczące harmonijności układu rozdziałów, ich hierarchizacji, sekwencyjnego ich wynikania, rzetelności i obiektywności w uzasadnianiu 
twierdzeń, ścisłości, jasności wywodów i źródłowości. Pewnym mankamentem jest brak rekapitulacji rozdziałów I, II, III. Rozdziały, podrozdziały, punkty nie powinny kończyć się tabelą (np. rozdział I), wykresem czy rysunkiem, lecz - zgodnie z zasadami logiczno-formalnymi - podsumowaniem lub wnioskami. W pracy, a także w tytułach rozdziałów, podrozdziałów i punktów nie należy używać skrótów i akronimów. Autor często posługuje się skrótem „versus” oraz akronimami, np. UE, RCA, IIT, UGW, UE, JRW itd. Może dobrze byłoby po spisie treści zamieścić wykaz użytych akronimów. Ponadto w wielu przywoływanych publikacjach brak jest wydawnictwa. Te drobne błędy formalne w niczym nie umniejszają wysokiej wartości merytorycznej recenzowanej monografii.

Podsumowując, uważam książkę prof. E.M. Plucińskiego za wybitne i oryginalne opracowanie naukowe bardzo ważnego problemu, o dużych wartościach poznawczych i utylitarnych. Wnosi ona wiele do poznania problemu konkurencyjności strukturalno-czynnikowej polskiego handlu zagranicznego na rynku Unii Europejskiej i w ogóle. Jest to niewątpliwie - jak do tej pory - najbardziej kompetentne i kompleksowe opracowanie wyżej wymienionych kwestii. Imponująca jest erudycja Autora, biegłość w posługiwaniu się skomplikowanymi statystykami, opanowanie metod i technik badawczych, logika wywodów i oryginalność sądów. Praca prezentuje wysoki poziom naukowy i zasługuje na wysoką ocenę. 